\title{
Tirofiban Hydrochloride
}

National Cancer Institute

\section{Source}

National Cancer Institute. Tirofiban Hydrochloride. NCI Thesaurus. Code C47759.

The hydrochloride salt form of tirofiban, a non-peptide tyrosine derivative with anticoagulant property. T irofiban antagonizes fibrinogen binding to the platelet cell surface receptor, glycoprotein (GP) IIb/IIIA complex, one of the two purinergic receptors activated by ADP. The antag onism prevents adenylyl cyclase activation, which mediated via GP IIb/IIla receptor complex, and results in decreased levels of cAMP and thereby interferes with platelet membrane function and subsequent platelet-platelet interaction, release of platelet granule constituents and prolongation of bleeding time. 